\title{
Studi Keandalan Ketersediaan Daya Pembangkit Listrik pada Jaringan Daerah " $X$ "
}

\author{
SYAHRIAL, KANIA SAWITRI, PARTRIANTI GEMAHAPSARI
}

Institut Teknologi Nasional Bandung

Email : syahrial.chaniago@gmail.com

\begin{abstract}
ABSTRAK
Keandalan tenaga listrik didefinisikan sebagai peluang dari suatu peralatan untuk beroperasi sesuai dengan fungsinya dalam suatu selang waktu tertentu dan dalam suatu kondisi operasi tertentu, sehingga dapat memenuhi kebutuhan listrik konsumen. Keandalan ketersediaan daya suatu sistem pembangkit dapat diketahui berdasarkan indeks keandalan yaitu LOLP (Loss of Load Probability) dan UE (Unserved Energy). Penelitian dilakukan dengan merancang 2 model konfigurasi sistem pembangkit berdasarkan nilai beban puncak, kemudian mengambil data laju kegagalan dan laju perbaikan dari masing-masing komponen sistem pembangkit yang selanjutnya dipakai untuk menghitung nilai FOR (Forced Outage Rate). Nilai FOR yang telah diperoleh digunakan untuk menghitung nilai indeks keandalan menggunakan metode segmentasi. Konfigurasi sistem pembangkit skenario ke-2 memiliki nilai indeks keandalan lebih kecil dibandingkan dengan konfigurasi sistem pembangkit skenario ke-1 yaitu dengan LOLP sebesar 0,0000088248 hari/tahun dan UE sebesar 0,0584 $K W H /$ tahun dengan total perkiraan biaya pada konfigurasi ini sebesar $R p$ 587.567.108,00.
\end{abstract}

Kata kunci: Keandalan, metode segmentasi, $L O L P, F O R, U E$

\begin{abstract}
The reliability of electric power is defined as the chance of an apparatus to operate in accordance with its function in a certain interval of time and in a certain operating conditions, so as to meet the electricity needs of consumers. The reliability of a power generation system availability can be determined based on the reliability index is LOLP (LOSS of Load Probability) and UE (Unserved Energy). The study was conducted by designing two models generating system configuration based on the value of the peak load, and then retrieve the data failure rate and the rate of repair of the individual components of the next generation system which is used to calculate the value FOR (Forced Outage Rate). FOR Value that has been obtained is used to calculate the reliability index using segmentation method. Generating system configuration scenarios to-2 has a reliability index value is smaller than the generating system configuration scenarios to- 1 that is by LOLP of 0.0000088248 days / year and the EU amounted to $0.0584 \mathrm{KWH} /$ year with a total estimated cost in this configuration Rp 587,567,108.00.
\end{abstract}

Keywords: Reliability, segmentation method, LOLP, FOR, UE 


\section{PENDAHULUAN}

Perkembangan teknologi memberikan pengaruh terhadap kebutuhan tenaga listrik yang semakin meningkat, baik di bidang industri maupun kebutuhan listrik rumah tangga. Peningkatan kebutuhan tenaga listrik juga harus diimbangi dengan keandalan sistem tenaga listrik, dalam hal ini adalah ketersediaan daya. Daya yang tersedia dalam sistem tenaga listrik haruslah cukup untuk melayani kebutuhan tenaga listrik dari konsumen.

Daya yang tersedia tergantung kepada daya terpasang unit-unit pembangkit dalam sistem dan juga tergantung kepada kesiapan operasi unit-unit tersebut. Berbagai faktor seperti gangguan kerusakan dan pemeliharaan rutin menyebabkan unit pembangkit menjadi tidak beroperasi. Jika gangguan ini terjadi pada saat yang bersamaan atas beberapa unit pembangkit yang besar, maka ada kemungkinan dilakukan pelepasan beban atau terpaksa sistem kehilangan beban. Jika pelepasan beban (pemadaman) sering terjadi maka dapat dikatakan sistem pembangkitan tidak andal dalam melayani beban (Ikzan, 2014; Marsudi, 1990). Kemungkinan bahwa sistem tidak dapat melayani beban dinyatakan dengan indeks unserved energy dan LOLP (loss of load probability) yang biasa dikenal dengan istilah probabilitas kehilangan beban. LOLP menggambarkan besar kecilnya peluang terhadap terjadinya kehilangan beban sebagai akibat kurangnya daya tersedia dalam sistem (Ikzan 2014; Marsudi, 2005). Unserved energy menunjukkan besar energi yang hilang sehubungan dengan kapasitas gangguan yang lebih besar daripada kapasitas cadangan atau kapasitas tersedia lebih kecil daripada permintaan beban maksimumnya (Ikzan, 2014).

Sistem pembangkit isolated dapat menjadi sumber daya listrik alternatif untuk mencukupi kebutuhan listrik di kawasan terpencil karena belum semua daerah atau rakyat di Indonesia dapat menikmati listrik. Hal ini disebabkan kebutuhan investasi yang besar, dan jangkauan saluran transmisi dan distribusi yang masih terbatas. Sistem pembangkit isolated merupakan sistem yang hanya mempunyai sebuah pusat listrik saja dan tidak ada interkoneksi antar pusat listrik serta tidak ada hubungan dengan jaringan umum (interkoneksi milik PLN) sehingga dapat meminimalisasi biaya investasi yang berkaitan dengan transmisi dan distribusi. Oleh karena itu, diperlukan suatu perencanaan yang baik untuk memperoleh tingkat keandalan pembangkitan yang baik. Berdasarkan latar belakang yang telah dipaparkan, maka rumusan masalah dalam penelitian ini adalah bagaimana merancang suatu sistem pembangkit listrik untuk mendapatkan nilai indeks keandalan yang baik dan bagaimana menentukan nilai keandalan sistem pembangkit listrik terhadap beberapa model konfigurasi sistem pembangkit dengan tujuan penelitian untuk mengetahui nilai indeks keandalan yang lebih baik diantara beberapa model konfigurasi sistem.

Keandalan merupakan peluang dari suatu peralatan untuk beroperasi seperti yang direncanakan dengan baik dalam suatu selang waktu tertentu dan berada dalam suatu kondisi operasi tertentu. Keandalan sistem tenaga listrik merupakan suatu ukuran tingkat pelayanan sistem terhadap pemenuhan kebutuhan energi listrik konsumen. Ada empat faktor yang berhubungan dengan keandalan, yaitu probabilitas, bekerja sesuai dengan fungsinya, periode waktu, dan kondisi operasi (Sulasno, 2001).

Suatu unit pembangkit dapat keluar dari sistem operasi tenaga listrik, sehingga tidak dapat membangkitkan energi listrik untuk mensuplai daya listrik. Dalam keadaan ini, unit pembangkit mengalami gangguan. Gangguan merupakan keadaan komponen jika tidak dapat melaksanakan fungsi sebenarnya akibat dari suatu atau beberapa kejadian yang berhubungan langsung dengan komponen tersebut. 
Gangguan ini dibedakan menjadi dua :

a. Gangguan paksa

Gangguan paksa adalah gangguan yang disebabkan oleh kondisi darurat yang berhubungan langsung dengan komponen/sistem/peralatan yang mengakibatkan komponen/sistem/peralatan harus dipisahkan dari sistem oleh suatu sistem proteksi secara otomatis atau manual oleh manusia.

b. Gangguan terencana

Gangguan terencana adalah gangguan yang menyebabkan komponen/sistem/peralatan dikeluarkan dari sistem. $\mathrm{Hal}$ ini biasanya dilakukan untuk perawatan komponen/sistem/peralatan tersebut yang telah direncanakan.

Keandalan unit-unit pembangkit dipengaruhi oleh berbagai faktor, antara lain gangguan kerusakan dan pemeliharaan rutin. Faktor-faktor tersebut memungkinkan unit-unit pembangkit mengalami keluar paksa (force outage). Ukuran sering tidaknya unit pembangkit mengalami gangguan dinyatakan dengan FOR (Forced Outage Rate).

Keandalan sistem pembangkitan dibagi menjadi dua aspek dasar, yaitu :

1. Adequacy sistem

Sistem kecukupan (adequacy) berkaitan dengan kecukupan fasilitas yang dibutuhkan sistem untuk memenuhi kebutuhan sistem. Hal ini meliputi fasilitas pembangkitan tenaga, transmisi dan distribusi yang diperlukan untuk menyalurkan energi yang dihasilkan ke beban. Kecukupan sistem dikaitkan dengan kondisi statis dari sistem dan tidak termasuk gangguan sistem.

2. Security sistem

Sistem keamanan (Security) berkaitan dengan kemampuan sistem untuk menanggapi gangguan yang timbul dalam sistem (Logahan, 2012). Oleh karena itu sistem keamanan dikaitkan dengan respon sistem untuk gangguan apa pun yang dikenakan.

Kehilangan beban (loss of load) adalah suatu kondisi dengan kapasitas daya yang tersedia lebih kecil dari beban sistem sehingga ada pelepasan sebagian beban. Probabilitas kehilangan beban (Loss of Load Probability) menyatakan besarnya nilai kemungkinan terjadinya kehilangan beban karena kapasitas daya tersedia sama atau lebih kecil dari beban sistem, yang dinyatakan dalam hari per tahun.

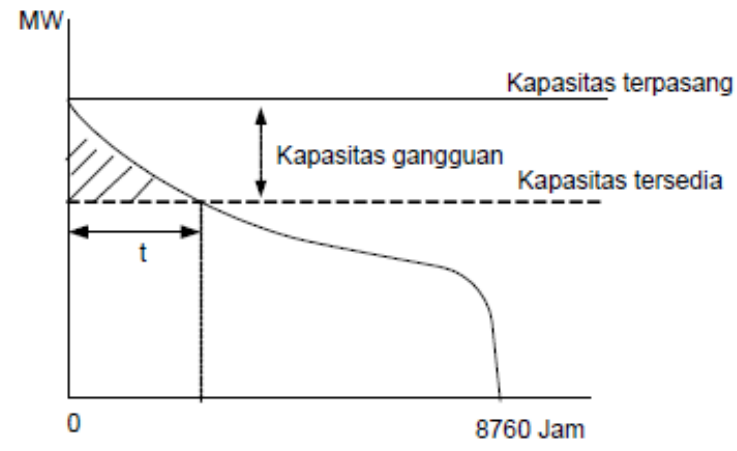

\section{Gambar 1. Kurva lama beban dan kapasitas tersedia dalam sistem}

Dari Gambar 1, terlihat bahwa garis kapasitas daya yang tersedia memotong garis kurva lama beban, sehingga menimbulkan kehilangan beban selama waktu t. Jadi secara umum :

dengan :

$$
\text { LOLP }=\mathrm{P} \times \mathrm{t}
$$

$\mathrm{P}=$ probabilitas terjadinya beban sama atau lebih besar dari besar daya tersedia.

$\mathrm{t}=$ waktu terjadinya kehilangan beban . 
Makin kecil nilai LOLP, makin baik keandalan sistem. Sebaliknya, semakin besar nilai LOLP, maka makin rendah keandalan system. Hal ini berarti bahwa probabilitas sistem tidak dapat melayani beban semakin besar.

Indeks keandalan energi elektrik yang belum dipenuhi (Unserved Energy, UE) menunjukkan besarnya energi yang hilang karena kapasitas tersedia lebih kecil dari permintaan beban maksimal. Indeks keandalan energi tak terpenuhi dinyatakan dalam satuan MWh/tahun. Gambar 2 menunjukkan kurva indeks keandalan energi tak terpenuhi.

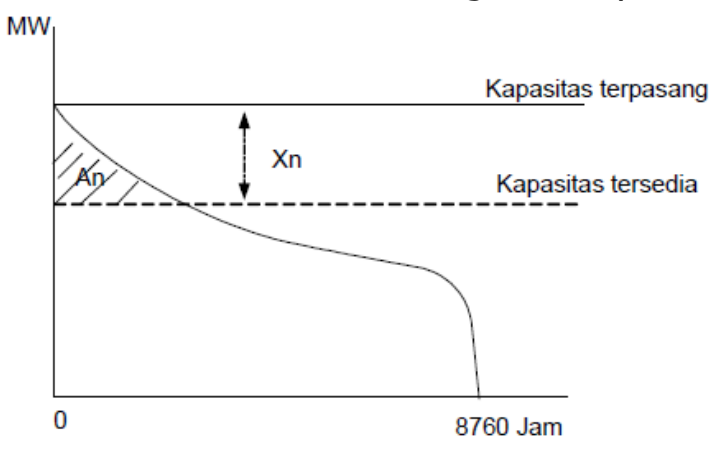

\section{Gambar 2. Kurva lama beban dan energi tak terpenuhi dalam sistem}

Luas daerah yang diarsir $\left(A_{n}\right)$ merupakan besarnya energi yang tak dapat terpenuhi oleh sistem pembangkitan yang disebabkan terjadinya gangguan sebesar $\mathrm{X}_{\mathrm{n}}$. Jika probabilitas kapasitas gangguan sebesar $X_{n}$ dinyatakan dengan $P_{n}$, maka hasil kali $A_{n}$ dan $P_{n}$ adalah probabilitas kehilangan energi yang disebabkan oleh kapasitas gangguan sebesar $\mathrm{Xn}$ (Marsudi, 1990).

$$
U E\left(X_{n}\right)=\sum A_{n} \cdot P_{n}
$$

\section{METODA PENELITIAN}

\subsection{Bagan Alur Pengerjaan (Flowchart)}

Metode perancangan merupakan uraian tahapan yang dilakukan dalam melaksanakan penelitian. Secara umum tahapan tersebut tertuang pada Gambar 3.
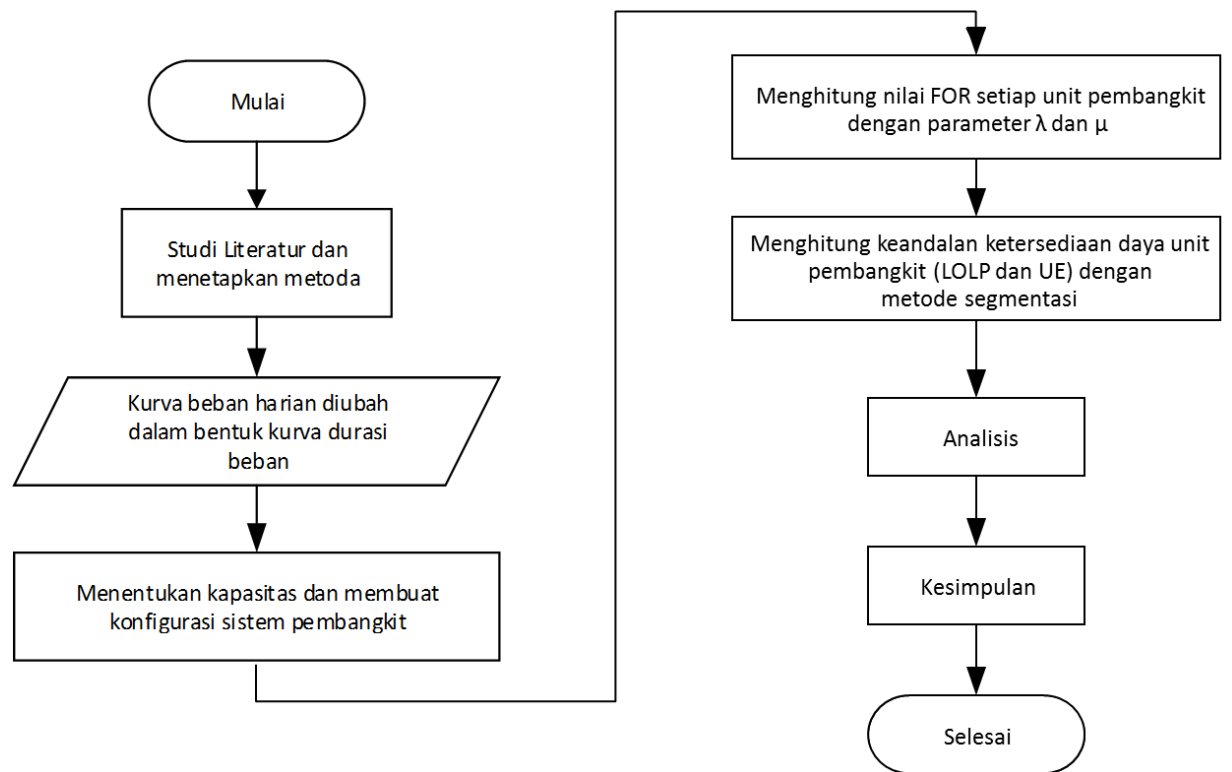

Gambar 3. Flowchart 
Penelitian diawali dengan melakukan studi literatur dan menetapkan metode. Selanjutnya data berupa kurva beban harian diubah ke dalam bentuk kurva durasi beban, menentukan kapasitas total pembangkit dengan menggunakan parameter nilai beban puncak, kemudian merancang konfigurasi sistem pembangkit yaitu menggunakan 2 model konfigurasi. Setelah itu, menghitung nilai FOR dengan menggunakan parameter laju kegagalan dan laju perbaikan tiap komponen. Nilai FOR akan digunakan untuk menghitung indeks keandalan LOLP dan UE dengan menggunakan metode segmentasi.

\subsection{Perencanaan Sistem Pembangkit}

Jenis pembangkit yang digunakan dalam perencanaan pada penelitian ini memakai pembangkit diesel. Parameter yang diperlukan dalam melakukan perencanaan kapasitas total sistem pembangkit adalah dengan mengetahui besar beban puncak harian. Umumnya perencanaan kapasitas pembangkit memperhitungkan besarnya faktor keamanan (safety factor) sebesar $20 \%$ dari nilai beban puncak. Perencanaan kapasitas total sistem pembangkit sebaiknya juga memiliki kapasitas cadangan yang dapat dimanfaatkan apabila dilakukan maintenance pada sistem. Besar nilai kapasitas total sistem pembangkit dihitung dengan cara sebagai berikut.

$$
\text { Kapasitas total pembangkit }=\text { nilai Bph }+(20 \% \times \text { nilai Bph })
$$

dengan Bph : Beban puncak harian

Setelah besar kapasitas total sistem pembangkit ditentukan, selanjutnya membuat model konfigurasi sistem pembangkit yang terdiri dari 2 skenario dan memiliki nilai kapasitas total sistem pembangkit yang sama dengan pembagian jumlah dan besar kapasitas generator sama. Skenario ke-1 terdiri dari 4 unit pembangkit (generator) dimana masing-masing generator terhubung seri dengan trafo. Skenario ke-2 terdiri dari 4 unit pembangkit (generator) dimana dua buah generator terhubung parallel.

\subsection{Perhitungan FOR (Forced Outage Rate)}

Ukuran sering tidaknya unit pembangkit mengalami gangguan dinyatakan dengan Forced Outage Rate (FOR) atau unavailability (Billinton, 1984).

$$
F O R=\frac{\lambda}{\lambda+\mu}
$$

keterangan:

$\lambda \quad$ : laju kegagalan

$\mu \quad$ : laju perbaikan

\subsection{Metode Segmentasi}

Metode segmentasi adalah metode yang menerapkan fungsi kerapatan probabilitas beban sebagai hasil dari pensamplingan beban tiap periode waktu yang digunakan (Hartono, 2005). Pensamplingan beban dilakukan untuk setiap jam. Fungsi kerapatan probabilitas hasil pensamplingan beban ini lalu dimasukkan ke segmen-segmen kapasitas sisi pembangkitan untuk ditentukan momen ke-nol dan momen pertama. Momen ke-nol adalah jumlah distribusi probabilitas beban dalam periode tertentu. Momen pertama adalah jumlah perkalian antara distribusi probabilitas dengan besar beban yang bersangkutan.

Metode segmentasi digunakan untuk mencari kemungkinan kehilangan beban dari sistem dan energi belum terpenuhi setelah mengkonvolusi seluruh unit pembangkit dalam sistem. Konvolusi unit pembangkit adalah proses untuk melibatkan suatu unit pembangkit dalam sistem pembangkitan untuk ikut memikul beban sistem (Hartono, 2005). 


\subsection{Perhitungan Indeks Keandalan dengan Metode Segmentasi}

Untuk menghitung kehilangan beban dan energi yang belum terpenuhi dengan konvolusi unit-unit pembangkit, maka kurva lama beban dibagi dalam segmen-segmen $\mathrm{KW}$ yang sama. Semakin kecil nilai segmen maka semakin teliti hasil yang didapatkan, tetapi semakin panjang proses perhitungan. Langkah-langkah dengan metode segmentasi adalah sebagai berikut.

1. Menentukan kapasitas total sistem pembangkit.

$$
\text { Kapasitas total sistem pembangkit }=\sum_{i=1}^{n} P_{i}
$$

2. Menentukan kapasitas setiap segmen (PK).

3. Kurva sistem beban harian dibuat kedalam fungsi kerapatan probabilitas beban.

4. Fungsi kerapatan probabilitas beban dimasukkan ke dalam segmen-segmen.

5. Menentukan jumlah distribusi probabilitas dan nilai rata-rata dari variabel acak (untuk mempermudah dibuat skematik blok).

6. Konvolusi unit pembangkit.

7. Perhitungan perubahan distribusi probabilitas dan nilai rata-rata dari variabel acak.

$$
\mathrm{m}_{1 \mathrm{i}}=\mathrm{m}_{1 \mathrm{i}} \text { lama }+ \text { (kapasitas pergeseran } \times \mathrm{m}_{0 \mathrm{i}} \text { ) }
$$

8. Perhitungan setelah terjadi pergeseran karena konvolusi.

$$
\begin{aligned}
& \mathrm{m}_{0 \mathrm{i}}=\left[\mathrm{m}_{0 \mathrm{i}} \text { lama } \times(1-\text { FOR })\right]+\left[\mathrm{m}_{0 \mathrm{i}} \text { baru } \times \text { FOR }\right] \\
& \mathrm{m}_{1 \mathrm{i}}=\left[\mathrm{m}_{1 \mathrm{i}} \text { lama } \times(1-\text { FOR })\right]+\left[\mathrm{m}_{1 \mathrm{i}} \text { baru } \times \text { FOR }\right]
\end{aligned}
$$

9. Perhitungan UE awal

$$
\mathrm{UE} \text { awal }=\sum_{\mathrm{i}=1}^{\mathrm{n}}\left(\mathrm{m}_{1 \mathrm{i}}\right) \times \mathrm{T}
$$

10. Perhitungan setelah konvolusi unit pembangkit pertama

$$
\text { UE unit } \mathrm{i}=\left(\left(\sum_{\mathrm{i}=1}^{\mathrm{y}} \mathrm{m}_{1 \mathrm{i}}\right)-\left(\text { kapasitas pergeseran } \times \sum_{\mathrm{i}=1}^{\mathrm{y}} \mathrm{m}_{0 \mathrm{i}}\right)\right) \times \mathrm{T}
$$

11. Perhitungan E unit pembangkit pertama

$$
\text { E unit ke }-\mathrm{i}=\mathrm{UE} \text { unit ke(i }-1)-\mathrm{UE} \text { unit ke }-\mathrm{i}
$$

12. Perhitungan $E$ total unit setelah konvolusi seluruh unit pembangkit

$$
\text { E total unit }=\sum_{i=1}^{n} E \text { unit ke }-i
$$

13. Perhitungan LOLP

$$
\text { LOLP sistem }=\sum_{\mathrm{i}=1}^{\mathrm{y}} \mathrm{m}_{0 \mathrm{i}}
$$

14. Perhitungan UE setelah konvolusi

$$
\mathrm{UE}=\mathrm{UE} \text { awal }-\mathrm{E} \text { total unit }
$$

\section{HASIL PERHITUNGAN DAN PEMBAHASAN}

\subsection{Keadaan Beban}

Dalam penelitian ini digunakan data beban harian yang ditunjukkan oleh Gambar 4. 


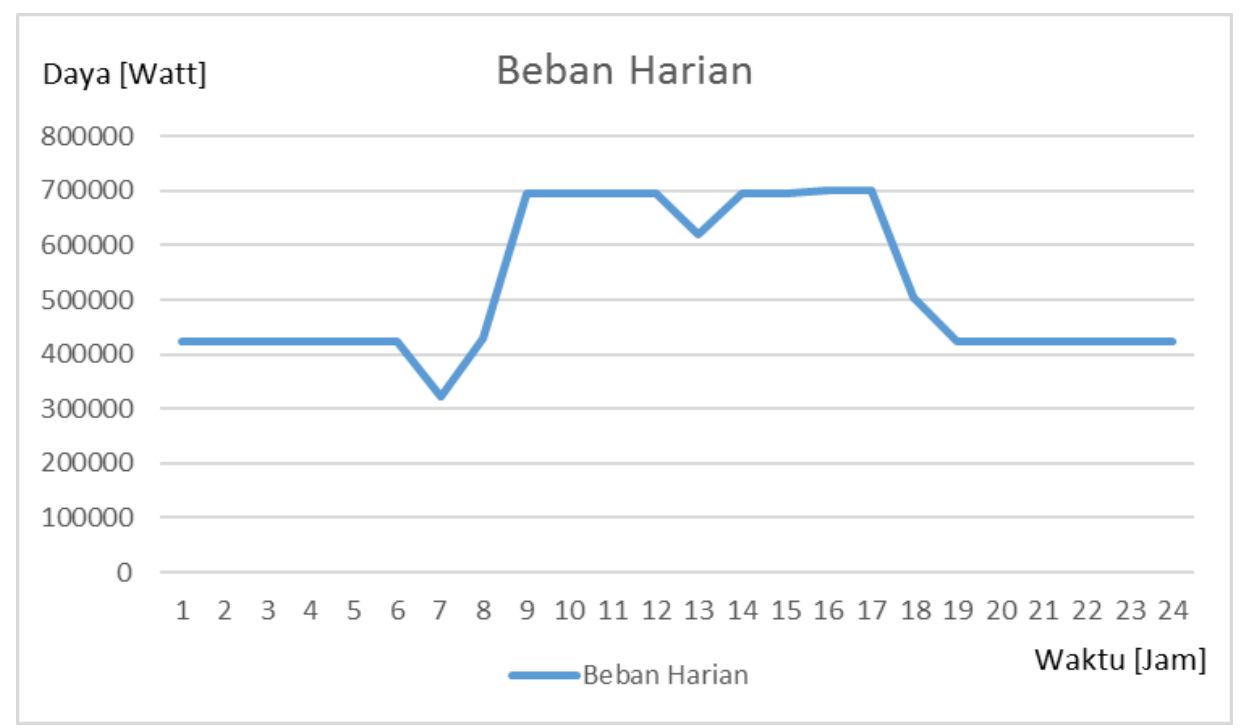

\section{Gambar 4. Kurva beban harian}

Pada Gambar 4 dapat terlihat bahwa beban tertinggi terjadi selama 2 jam sekitar pukul 15.00-17.00 sebesar 699860 watt. Hal tersebut terjadi karena masih terdapat peralatan yang beroperasi dengan daya yang cukup tinggi. Dari gambar kurva beban tersebut dapat disimpulkan bahwa konsumsi listrik pada siang dan sore hari cenderung lebih besar dibandingkan pagi dan malam hari. Agar memudahkan perhitungan, maka kurva beban harian sebagai fungsi sesaat perlu diubah menjadi kurva durasi beban seperti pada Gambar 5.

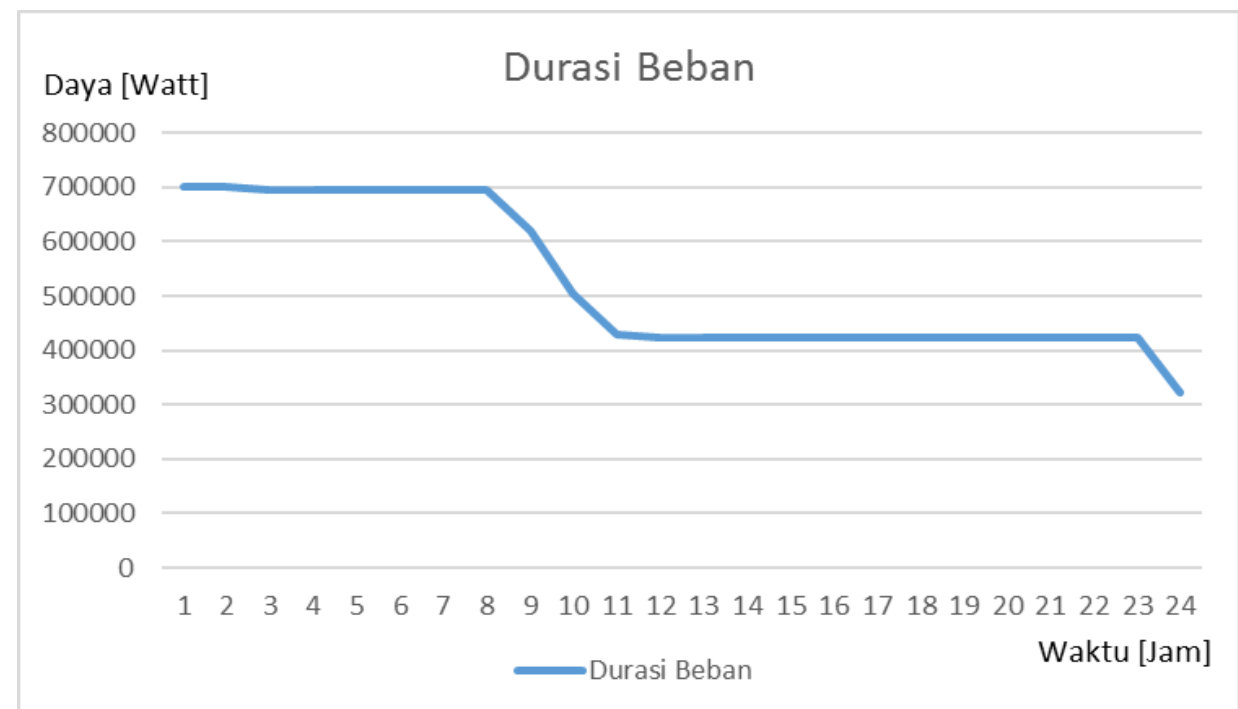

\section{Gambar 5. Kurva durasi beban}

Pada Gambar 5 dapat terlihat beban tertinggi berada di bagian kiri dan beban terendah berada di bagian kanan.

\subsection{Perencanaan Kapasitas Pembangkit}

Berdasarkan kurva beban harian, diperoleh nilai beban puncak harian sebesar 699860 watt dan akan dibulatkan menjadi $700 \mathrm{KW}$, maka kapasitas total sistem pembangkit yang diperlukan sebesar :

$$
\text { Kapasitas total pembangkit }=700 \mathrm{KW}+(20 \% \times 700 \mathrm{KW})=840 \mathrm{KW}
$$




\subsection{Konfigurasi Sistem Pembangkit yang Diskenariokan}

Pada penelitian ini, terdapat 2 model konfigurasi sistem pembangkit yang diskenariokan sebagai berikut.

1. Menggunakan 4 unit pembangkit diesel dengan kapasitas unit pembangkit 1 , unit pembangkit 2, unit pembangkit 3, dan unit pembangkit 4 adalah sama masingmasing sebesar $1 \times 280 \mathrm{KW}$. Gambar 6(a) menunjukkan konfigurasi sistem pembangkit skenario ke-1.

2. Menggunakan 4 unit pembangkit diesel dengan kapasitas unit pembangkit 1 , unit pembangkit 2, unit pembangkit 3, dan unit pembangkit 4 adalah sama masingmasing sebesar $1 \times 280 \mathrm{KW}$. Gambar 6(b) menunjukkan konfigurasi sistem pembangkit skenario ke-2.

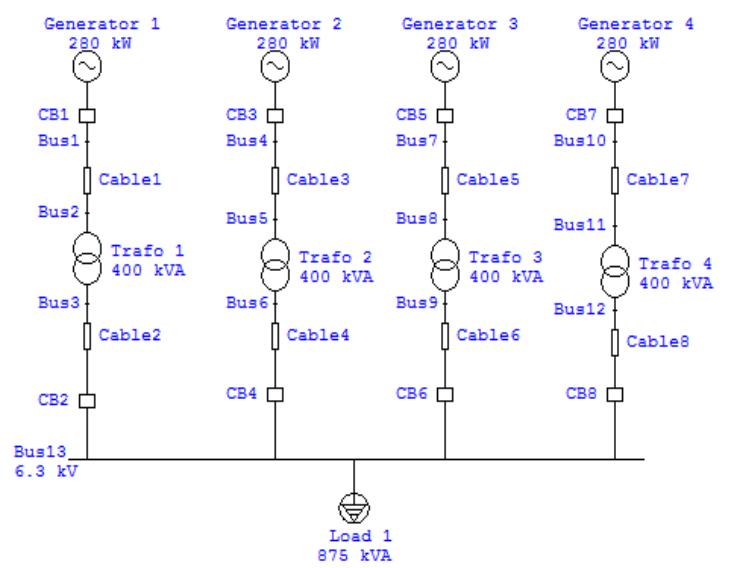

(a)

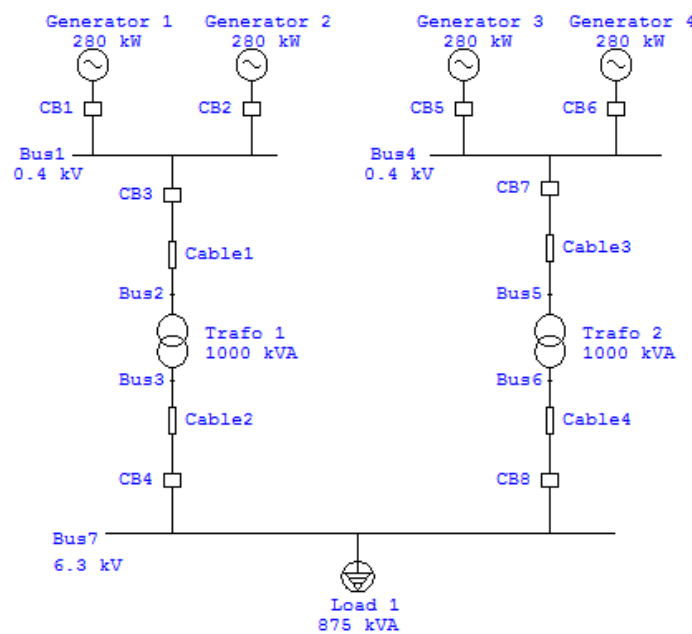

(b)

Gambar 6 (a) Konfigurasi sistem pembangkit skenario ke-1 ; (b) Konfigurasi sistem pembangkit skenario ke-2

\subsection{Hasil Perhitungan}

\subsubsection{FOR (Forced Outage Rate)}

Perhitungan FOR didapatkan dengan menggunakan data-data sebagai berikut.

Tabel 1. Laju kegagalan dan laju perbaikan tiap komponen unit pembangkit

\begin{tabular}{|c|c|c|c|}
\hline No & Parameter & $\begin{array}{c}\boldsymbol{\lambda} \\
\text { (failure/yr) }\end{array}$ & $\begin{array}{c}\boldsymbol{\mu} \\
\text { (repair/yr) }\end{array}$ \\
\hline 1 & Generator & 0,638 & 46,1053 \\
\hline 2 & Circuit Breaker & 0,009 & 140,3846 \\
\hline 3 & Transformator 1 & 0,0074 & 178,7755 \\
\hline 4 & Transformator 2 & 0,005 & 29,4949 \\
\hline 5 & Kabel & 0,0606 & 177,3279 \\
\hline 6 & Busbar & 0,001 & 4380 \\
\hline
\end{tabular}

Tabel 1 merupakan nilai laju kegagalan dan laju perbaikan tiap komponen yang didapat dengan bantuan software ETAP. Laju kegagalan dan laju perbaikan kabel masih dinyatakan dalam bentuk $1 \mathrm{~km}$ per satuan panjang. Selanjutnya dilakukan perhitungan nilai laju kegagalan dan laju perbaikan untuk setiap unit pembangkit kemudian akan didapatkan nilai 
FOR dengan Persamaan 4. Nilai FOR untuk masing-masing pembangkit seperti yang ditunjukkan oleh Tabel 2.

Tabel 2. Hasil perhitungan nilai FOR

\begin{tabular}{|c|c|c|}
\hline $\begin{array}{c}\text { Konfigurasi } \\
\text { Sistem Pembangkit } \\
\text { Skenario ke- }\end{array}$ & $\begin{array}{c}\text { Kapasitas } \\
(\mathbf{K W})\end{array}$ & FOR \\
\hline \multirow{4}{*}{1} & $1 \times 280$ & \multirow{4}{*}{$1,300181 \times 10^{-3}$} \\
\hline & $1 \times 280$ & \\
\hline & $1 \times 280$ & \\
\hline & $1 \times 280$ & \\
\hline \multirow{4}{*}{2} & $1 \times 280$ & $1,37795 \times 10^{-4}$ \\
\hline & $1 \times 280$ & $7,2939 \times 10^{-5}$ \\
\hline & $1 \times 280$ & $1,37795 \times 10^{-4}$ \\
\hline & $1 \times 280$ & $7,2939 \times 10^{-5}$ \\
\hline
\end{tabular}

Berdasarkan Tabel 2 dapat terlihat nilai FOR untuk keempat unit pembangkit pada konfigurasi skenario 1 memiliki nilai yang sama sedangkan nilai FOR untuk keempat unit pembangkit pada konfigurasi skenario 2 memiliki nilai yang berbeda antar unit pembangkit. Hal ini disebabkan oleh bentuk dari konfigurasi yang digunakan pada masing-masing skenario.

\subsubsection{Sampling Beban}

Pensamplingan beban tiap jam dapat dinyatakan dengan fungsi kerapatan probabilitas ditunjukkan oleh Gambar 7.

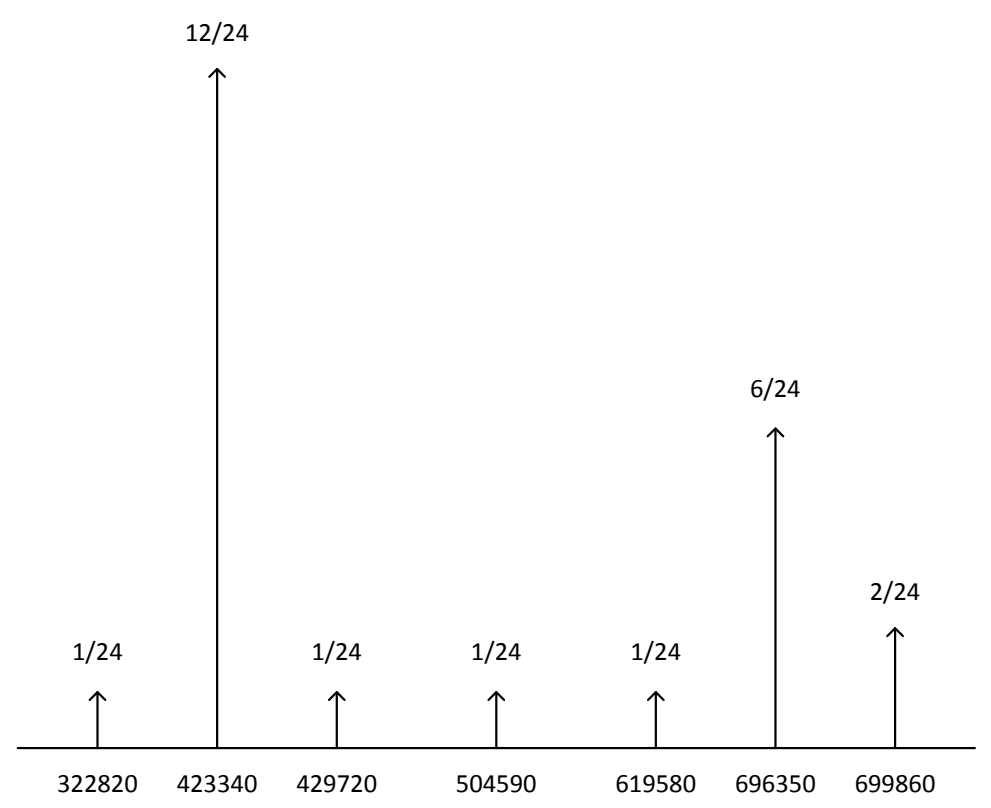

Gambar 7. Fungsi kerapatan probabilitas beban harian

Gambar 7 menunjukkan hubungan antara nilai beban dengan durasi beban yang selanjutnya akan digunakan pada metode segmentasi. 


\subsubsection{Indeks Keandalan LOLP (Loss of Load Probability)}

Besarnya nilai LOLP dapat dihitung dengan menggunakan Persamaan 7 dan Persamaan 13 yang hasilnya dapat dilihat pada Tabel 3.

Tabel 3. Hasil perhitungan nilai LOLP

\begin{tabular}{|c|c|}
\hline $\begin{array}{c}\text { Konfigurasi } \\
\text { Sistem Pembangkit } \\
\text { Skenario ke- }\end{array}$ & $\begin{array}{c}\text { LOLP } \\
\text { (hari/tahun) }\end{array}$ \\
\hline 1 & 0,00138714 \\
\hline 2 & 0,0000088248 \\
\hline
\end{tabular}

Berdasarkan Tabel 3, konfigurasi skenario 2 memiliki nilai LOLP lebih kecil dibandingkan konfigurasi skenario 1.

\subsubsection{Indeks Keandalan UE (Unserved Energy)}

Besarnya nilai UE dapat dihitung dengan menggunakan Persamaan 8 sampai dengan Persamaan 13 (kecuali Persamaan 12) yang hasilnya dapat dilihat pada Tabel 4.

Tabel 4. Hasil perhitungan nilai UE

\begin{tabular}{|c|c|}
\hline $\begin{array}{c}\text { Konfigurasi } \\
\text { Sistem Pembangkit } \\
\text { Skenario ke- }\end{array}$ & $\begin{array}{c}\text { UE } \\
\text { (KWH/tahun) }\end{array}$ \\
\hline 1 & 93,305 \\
\hline 2 & 0,0584 \\
\hline
\end{tabular}

Berdasarkan Tabel 4, konfigurasi skenario 2 memiliki nilai UE lebih kecil dibandingkan konfigurasi skenario 1.

\subsection{Perkiraan Biaya Pembangkit}

Untuk menentukan keandalan suatu pembangkit perlu mempertimbangkan pula mengenai biaya untuk masing-masing konfigurasi.

\section{a. Konfigurasi 1}

Untuk mengetahui komponen yang akan digunakan maka dilakukan perhitungan sebagai berikut.

CB sebelum trafo $(\mathrm{CB} 1=\mathrm{CB} 3=\mathrm{CB} 5=\mathrm{CB} 7)$

$$
\mathrm{I}=\frac{\mathrm{s}}{\sqrt{3} \mathrm{~V}_{\mathrm{LL}}}=\frac{350000}{\sqrt{3} 400}=505,181 \mathrm{~A}
$$

Berdasarkan perhitungan, maka CB sebelum trafo menggunakan MCCB Compact NSX630F merek Schneider dengan kemampuan arus $630 \mathrm{~A}$.

$\mathrm{CB} 2=\mathrm{CB} 4=\mathrm{CB} 6=\mathrm{CB} 8$

$$
\mathrm{I}=\frac{\mathrm{s}}{\sqrt{3} \mathrm{~V}_{\mathrm{LL}}}=\frac{400000}{\sqrt{3} 6300}=36,657 \mathrm{~A}
$$

Berdasarkan perhitungan, maka CB setelah trafo menggunakan HVX Vacuum Circuit Breaker $630 \mathrm{~A}$. 
Kabel sebelum trafo (Kabel $1=$ Kabel $3=$ Kabel $5=$ Kabel 7)

$$
\begin{aligned}
& \mathrm{I}=\frac{\mathrm{s}}{\sqrt{3} \mathrm{~V}_{\mathrm{LL}}}=\frac{350000}{\sqrt{3} 400}=505,181 \mathrm{~A} \\
& \mathrm{KHA}=125 \% \times \mathrm{I}=\frac{125}{100} \times 505,18=631,475 \mathrm{~A}
\end{aligned}
$$

Berdasarkan perhitungan, maka kabel sebelum trafo menggunakan kabel N2XSY $1 \times 95 \mathrm{~mm}^{2}$ $3,6 \mathrm{KV}$.

\section{Kabel setelah trafo (Kabel $2=$ Kabel $4=$ Kabel $6=$ Kabel 8 )}

$$
\begin{aligned}
& \mathrm{I}=\frac{\mathrm{s}}{\sqrt{3} \mathrm{~V}_{\mathrm{LL}}}=\frac{400000}{\sqrt{3} 6300}=36,657 \mathrm{~A} \\
& \mathrm{KHA}=125 \% \mathrm{xI}=\frac{125}{100} \times 36,657=45,821 \mathrm{~A}
\end{aligned}
$$

Berdasarkan perhitungan, maka kabel setelah trafo menggunakan kabel N2XSEY 3 × 35mm² $12 \mathrm{KV}$.

Setelah dilakukan perhitungan, konfigurasi skenario 1 diperlukan biaya pembangkit seperti pada Tabel 5.

Tabel 5. Perkiraan biaya konfigurasi pembangkit skenario 1

\begin{tabular}{|l|c|c|c|}
\hline \multicolumn{1}{|c|}{ Nama Komponen } & $\begin{array}{c}\text { Harga } \\
(\mathbf{R p )}\end{array}$ & Jumlah & $\begin{array}{c}\text { Total Harga } \\
(\mathbf{R p )}\end{array}$ \\
\hline Diese/ Generator Cummins 350 kVA & $656.926,9$ & 4 & $2.627 .707,6$ \\
\hline Trafo Schneider 400 kVA & 88.000 .000 & 4 & 352.000 .000 \\
\hline MCCB Compact NSX360F & 8.536 .000 & 4 & 34.144 .000 \\
\hline HVX Vacuum Circuit Breaker 630 A & 80.000 .000 & 4 & 320.000 .000 \\
\hline N2XSY 1 x 95 mm² - 1,8/3 (3,6) kV & 129.000 & & 30.960 .000 \\
\hline N2XSEY 3 x 35 mm2 - 6/10 (12) kV & 400.500 & \multicolumn{3}{|c|}{32.040 .000} \\
\hline Total & \multicolumn{3}{|c|}{$771.771 .707,6$} \\
\hline
\end{tabular}

\section{b. Konfigurasi 2}

Untuk mengetahui komponen yang akan digunakan maka dilakukan perhitungan sebagai berikut.

\section{CB sebelum trafo dan sebelum bus 0,4 kV (CB $1=C B 2=\mathrm{CB} 5=\mathrm{CB} 6)$}

$$
\mathrm{I}=\frac{\mathrm{s}}{\sqrt{3} \mathrm{~V}_{\mathrm{LL}}}=\frac{350000}{\sqrt{3} 400}=505,181 \mathrm{~A}
$$

Berdasarkan perhitungan, maka $\mathrm{CB}$ sebelum trafo dan sebelum bus $0,4 \mathrm{kV}$ menggunakan MCCB Compact NSX630F merek Schneider dengan kemampuan arus 630 A.

\section{CB sebelum trafo dan setelah bus 0,4 kV (CB 3 = CB 7)}

$$
\mathrm{I}=\mathrm{I}_{1}+\mathrm{I}_{2}=505,181+505,181=1010,362 \mathrm{~A}
$$

Berdasarkan perhitungan, maka CB sebelum trafo menggunakan MCCB Compact NS1250N merek Schneider dengan kemampuan arus $1250 \mathrm{~A}$.

\section{CB setelah trafo da 0,4 kV (CB 4 = CB 8)}

$$
\mathrm{I}=\frac{\mathrm{s}}{\sqrt{3} \mathrm{~V}_{\mathrm{LL}}}=\frac{1000000}{\sqrt{3} 6300}=91,64 \mathrm{~A}
$$


Berdasarkan perhitungan, maka CB sebelum trafo menggunakan HVX Vacuum Circuit Breaker630 A.

\section{Kabel sebelum trafo (Kabel 1 = Kabel 3)}

$$
\begin{aligned}
& \mathrm{I}=\mathrm{I}_{1}+\mathrm{I}_{2}=505,181+505,181=1010,362 \mathrm{~A} \\
& \mathrm{KHA}=125 \% \mathrm{xI}=\frac{125}{100} \times 1010,362=1262,953 \mathrm{~A}
\end{aligned}
$$

Berdasarkan perhitungan, maka kabel sebelum trafo menggunakan kabel N2XSY $1 \times 150 \mathrm{~mm}^{2}$ $3,6 \mathrm{KV}$.

\section{Kabel setelah trafo (Kabel 2 = Kabel 4)}

$$
\begin{aligned}
& \mathrm{I}=\frac{\mathrm{s}}{\sqrt{3} V_{\mathrm{LL}}}=\frac{1000000}{\sqrt{3} 6300}=91,64 \mathrm{~A} \\
& \mathrm{KHA}=125 \% \mathrm{xI}=\frac{125}{100} \times 91,64=114,55 \mathrm{~A}
\end{aligned}
$$

Berdasarkan perhitungan, maka kabel setelah trafo menggunakan kabel N2XSEY $3 \times 35 \mathrm{~mm}^{2}$ $12 \mathrm{KV}$.

\begin{tabular}{|c|c|c|c|}
\hline Nama Komponen & $\begin{array}{l}\text { Harga } \\
(\mathrm{Rp})\end{array}$ & Jumlah & $\begin{array}{c}\text { Total Harga } \\
(\mathbf{R p})\end{array}$ \\
\hline Diesel Generator Cummins 350 kVA & $656.926,9$ & 4 & $2.627 .707,6$ \\
\hline Trafo Schneider 1000 kVA & 148.500 .000 & 2 & 297.000 .000 \\
\hline MCCB Compact NSX360F & 8.536 .000 & 4 & 34.144 .000 \\
\hline MCCB Compact NS1250N & 21.787 .700 & 2 & 43.575 .400 \\
\hline HVX Vacuum Circuit Breaker $630 \mathrm{~A}$ & 80.000 .000 & 2 & 160.000 .000 \\
\hline $\mathrm{N} 2 \mathrm{XSY} 1 \times 150 \mathrm{~mm}^{2}-1,8 / 3(3,6) \mathrm{kV}$ & 190.000 & & 68.400 .000 \\
\hline N2XSEY $3 \times 35$ mm2 - 6/10 (12) kV & 400.500 & & 16.020 .000 \\
\hline Total & \multicolumn{3}{|c|}{$587.567 .107,6$} \\
\hline
\end{tabular}

Setelah dilakukan perhitungan, konfigurasi skenario 2 diperlukan biaya pembangkit seperti pada Tabel 6.

Tabel 6. Perkiraan biaya konfigurasi pembangkit skenario 2

\section{KESIMPULAN}

Setelah melakukan perencanaan sistem pembangkit terhadap beberapa model konfigurasi sistem pembangkit maka dapat ditarik kesimpulan sebagai berikut.

1. Konfigurasi sistem pembangkit skenario ke-1 terdiri dari 4 unit pembangkit diesel dengan kapasitas unit pembangkit 1 , unit pembangkit 2, unit pembangkit 3, dan unit pembangkit 4 adalah sama sebesar $1 \times 280 \mathrm{KW}$ dengan nilai FOR 1,300181 x 10-3. Pada konfigurasi ini diperoleh nilai LOLP sebesar 0,00138714 hari/tahun dan UE sebesar 93,305 KWH/tahun. Total perkiraan biaya pada konfigurasi ini sebesar Rp 771.771.708,00.

2. Konfigurasi sistem pembangkit skenario ke-2 terdiri dari 4 unit pembangkit diesel dengan kapasitas unit pembangkit 1 , unit pembangkit 2, unit pembangkit 3, dan unit pembangkit 4 adalah sama sebesar $1 \times 280 \mathrm{KW}$. Unit pembangkit 1 dan unit pembangkit 3 memiliki nilai FOR $1,37795 \times 10^{-4}$. Unit pembangkit 2 dan unit pembangkit 4 memiliki nilai FOR 7,2939 $\mathrm{x}$ $10^{-5}$. Pada konfigurasi ini diperoleh nilai LOLP sebesar 0,0000088248 hari/tahun dan UE 
sebesar 0,0584 KWH/tahun. Total perkiraan biaya pada konfigurasi ini sebesar Rp 587.567.108,00.

3. Apabila terjadi maintenance unit pembangkit, maka konfigurasi sistem pembangkit skenario ke-2 akan berisiko dalam memenuhi kebutuhan beban. Namun untuk mengatasi risiko tersebut perlu disediakan cadangan yaitu sekuriti $(n-1)$ dengan biaya investasi yang lebih besar.

\section{DAFTAR RUJUKAN}

Billinton R, Allan RN. (1984). Reliability Evaluation of Power System. New York: Plenum Press.

Hartono. (2005). Perbandingan Simulasi Probabilitas Produksi Sistem Tenaga Metode Segmentasi dibandingkan Metode Fungsi Energi Ekuivalen. Depok: Pascasarjana UI.

Ikzan. (2014). Studi Keandalan Ketersediaan Daya Perencanaan Pembangkit Listrik PT PLN Sistem SulSelBar Tahun 2010-2020. Tugas Akhir.

Logahan Pingkan A. (2012). Keandalan Sistem Pembangkit Terdistribusi dengan Pembangkit Diesel, Angin dan PV. Tesis.

Marsudi, D. (1990). Operasi Sistem Tenaga Listrik. Jakarta: Balai Penerbit \& Humas ISTN.

Marsudi, D. (2005). Pembangkitan Energi Listrik. Jakarta: Erlangga.

Sulasno. (2001). Teknik dan Sistem Distribusi Tenaga Listrik. Semarang: Universitas Diponegoro. 